\title{
A Study on Le Corbusier's Carpenter Center for the Visual Arts: Focused on Experience of Architectural Promenade
}

\author{
Kim, Nam Hoon \\ Assistant professor of College of Architecture at Myongji University
}

\begin{abstract}
The purpose of this study is to reveal the meaning of ramp of Le Corbusier's Carpenter Center for the Visual Arts focused on experience of architectural promenade. The Carpenter Center was completed in 1964, only a year earlier than the death of Le Corbusier and also, this building is the only building actually constructed in North America. Despite these important facts, the meanings of the ideas of this building have not been paid attention as much as other buildings constructed at the same period, such as, Venice Hospital and Un Pavillion D'exposition in Zurich. In his book, 'Oeuvre Complète 1957-1965', Le Corbusier mentioned Carpenter Center as an architectural experiments of his ideas. The study of carpenter center will be an important architectural subject to clarify the meaning of his later works and ideas.
\end{abstract}

Keywords : Le Corbusier, Carpenter Center for the Visual Arts, Space, Construction

\section{INTRODUCTION}

\section{(1) Purpose of Study}

Le Corbusier died at the age of 78 in 1965. 330 projects were designed for his lifetime. Among them, 100 works were constructed and about 50 pieces of books were published. Beatriz Colomina mentioned him as the most frequently written architect in the $20^{\text {th }}$ century. ${ }^{1}$

For his lifetime, Corbusier has completed master pieces all over the world. However, only one building was constructed in North America. Several attempts had been made for Corbusier to realize projects at the United States such as competition entry of United Nations in 1947. The finally realized project was rather small building, compared to his continued efforts and passion.

This unique work is Carpenter Center for the Visual Arts of Harvard University. About 2 years have passed from negotiation

\footnotetext{
${ }^{1}$ Beatriz Colomina, Privacy and Publicity, MIT press, p.p. 16-17, 1996

Corresponding Author: Nam Hoon Kim, Assistant Professor College of Architecture, Myongji University San 38-2 Nam-Dong, Cheoin-Gu, Yongin-Si, Gyeonggi-Do, 449-728, Korea

Tel: +82 313306483 e-mail : knamhoon@mju.ac.kr

This is an Open Access article distributed under the terms of the Creative Commons Attribution Non-Commercial License (http://creativecommons. org/licenses/by-nc/3.0/) which permits unrestricted non-commercial use, distribution, and reproduction in any medium, provided the original work is properly cited.
}

with Corbusier to contract after the decision made. It took about 5 years from design to completion. That is just one year before his death. In the last volume of 'Compete Works (Oeuvre Complète) 1957-1965', he expressed Carpenter Center as "an example of Le Corbusier theories - une démonstration des théories de le Corbusier --- Typical and unique ideas unfolded in various directions-de nombreuses idées directrices qui lui sont propres" ${ }^{2}$. Like this, Carpenter Center shows formal features of architectural experiments, in particular, found in his late works, such as brisesoleils, ondulatoires, pilotis, roof garden, ramp and exposed concrete and etc.

Most of the research concerning Carpenter Center is focused on two directions. The first one is to find out the related architectural discourses and the other is tracing formal design elements found in Corbusier's works chronically by comparing with his architecture of same or previous period. ${ }^{3}$ Many critics argued that the huge ramp of Carpenter Center is exaggerated too much and has the simple function penetrating buildings. Furthermore, workshops which occupy the most of building area, look like huge warehouse and interior space having no spatial interests has been always the target of criticism. This is one of reasons why Carpenter Center have not been paid attention as much as other buildings constructed at the same period.

\footnotetext{
${ }^{2}$ Sekler \& Curtis, Le Corbusier at work- the genesis of the Carpenter Center for the Visual Arts, pp.2-3,1978

${ }^{3}$ Kenneth Frampton, In the footsteps of Le Corbusier, 'Le Corbusier and the Dialectical imagination' - Architectural analysis of formal similarity from Carpenter Center for the Visual Arts with Mill Owners' Association Building, Rizzoli International. p.p.243-249, 1991
} 
This study aims to analyze the meaning of such elements in different directions through documents and drawing of whole design process and construction period rather than simply approaching features of buildings.

\section{(2) Methodology}

Most of analysis will focus on elements related in the design process from 1958 to 1965 when the project was completed. Since limited communication method exist, massive amount of drawings and official letters had been exchanged between Paris atelier of Corbusier and Boston office of Jose Luis Sert, a collaborative architect. Corbusier's original sketches and documents about design process are stored in Corbusier Foundation (FLC) in Paris. These were referred to as the data for this research. Another important reference is the book titled 'Le Corbusier at Works, the Genesis of the Carpenter Center for the Visual Arts' edited by Eduard F. Sekler and William Curtis. This is an archive issued by Harvard University and helped to comprehend criticism of theorists about Carpenter Center.

\section{MAIN DISCUSSION}

\section{(1) Background of Project}

Corbusier's only one complete project in the North America is located at the campus of Harvard University, Contrary to Yale University which was well-known for fine art department; Harvard University doesn't have fine art major. So, it is rather strange to design the place for arts education for students who are not majoring in fine arts.

At that time, the United States had suffered from various social and cultural transformations after the World War II. The university wanted symbolic place to reflect the request for the avant-garde arts denying existing paradigm of traditional fine arts. In the end, The Center for the Visual Arts was pursued as the necessity of ideal place for arts education under the goal of 'Meeting place of young people interested in experimenting with the visual media." ${ }^{4} \mathrm{New}$ modern architecture for this goal symbolized internal change of school and means important starting point to transform university externally.

At that time, the University accepted such request with active recommendation of Jose Luis Sert, dean of Graduate School of Design. It was meaningful to the school that Corbusier, the master of modern architecture, took in charge of designing new arts education center.

\section{(2) Problems in Design}

Alfred S. V. Carpenter who contributed the fund to realize project, wanted to place this building facing Charles River. However, there was no suitable place among the riverside areas owned by Harvard University. Finally, the empty space between Faculty Club and Fogg Art museum of Quincy St was selected. This place was facing Harvard Yard, where dormitory for freshmen and undergraduate classroom were located. ${ }^{6}$

Surrounding campus buildings were all classicism style, and located in Cartesian grid system. Organic curved shape of Carpenter Center finished with exposed concrete was new typology totally different from the existing campus buildings.(Fig.1). Historian Henry Russell Hitchcock expressed a strong disagreement with the site selection and the awkward relationship between building and its immediate surroundings ${ }^{7}$ and criticized that selection of site for Carpenter Center was unsuitable. Even though, the site selection seemed to be determined with agreement between the school and Corbusier at least. Corbusier showed bigger difference in area of size than in site location. On the other hand, the school worried that the given site was too big for the floor areas of Carpenter Center $^{8}$. However in the 'Oeuvre Complète' the tightness of the site is described as a challenge. "The problem consisted of creating the circulation, places of work, to find surfaces and lighting and, the most difficult of all; it consisted of inserting all of this in so little space. The problem was not easy". Aerial photograph (Fig. 1.) shows that Carpenter Center for the Visual Arts had definitely lager areas compared to surrounding buildings.

Because the building was constructed in the initially selected site without change, all the problems he mentioned might be solved though the design process.
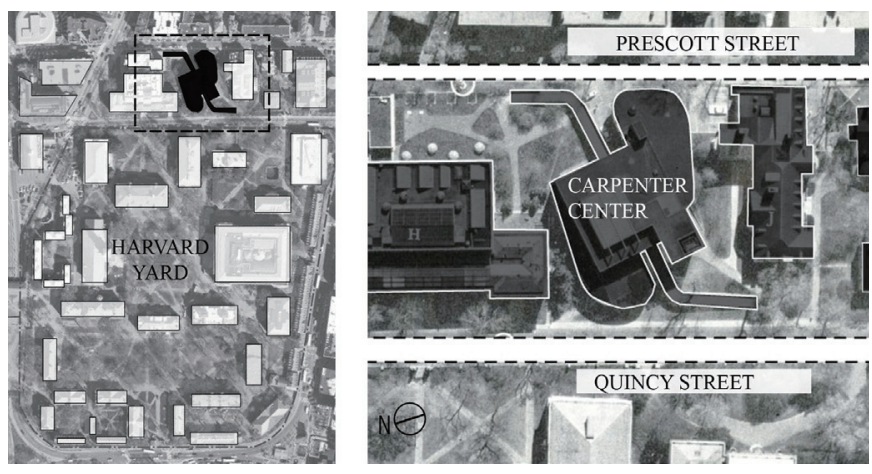

Figure 1. Aerial view of Carpenter Center for the Visual Arts Left is the layout including Harvard Yard. / Right is Carpenter Center for the Visual Arts between Faculty Club and Fogg Art Museum. (Aerial Photograph in 1964)

\footnotetext{
${ }^{6}$ Harvard University was first established in 1636 and is the oldest school in USA. Harvard Yard was the place where old campus was located and is the center of campus that has kept the original shapes for over 300 years.

${ }^{7}$ Henry Russell Hitchcock, Le Corbusier and the United States, Zodiac, 1966.

${ }^{8}$ See the letter sent by Sert to Corbusier 1960, Aug. 31 / FLC, J3-7 88 (Director of Corbusier Foundation)

${ }^{9}$ Le Corbusier, Oeuvre Complète 1957-65, Birkhauser, p.54, 1965, 2006
}

\footnotetext{
${ }^{4}$ Report of the Committee on the Practice of the Visual Arts - Sekler \& Curtis, Le Corbusier at work, p.p.278-283, 1978

${ }^{5}$ Harvard University was the place of new architectural experiment until the end of 19th century including H.H. Richardson, the pioneer of American modern architecture. However, no new attempt has been made in 20th century. On the other hands, In the M.I.T, Alva alto completed Baker House in 1947, cathedral and chapel of Eero Saarinen was constructed in 1955 as well as many modern buildings. Harvard University wants to build progressive works of modern architect.
} 


\section{(3) How to Construct Circulation System}

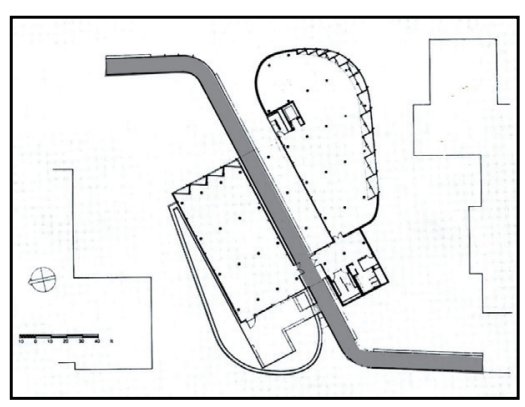

Figure 2. 3rd Floor Plan- gray color indicates the ramp penetrating the building

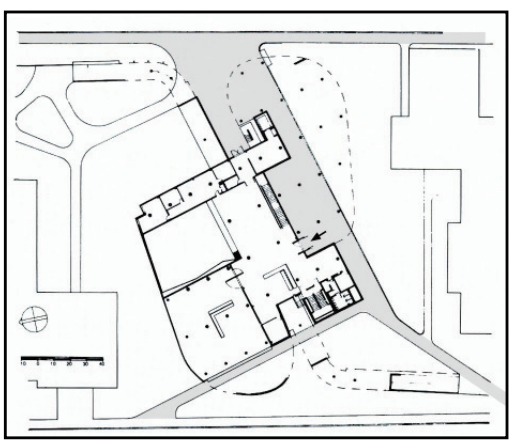

Figure 3. Ground Floor Plan - gray color indicates pedestrian path
One of the most conspicuous formal features in Carpenter Center for the Visual Arts is the big ramp penetrating the building. In June 8 1960, there was the first presentation about design of Carpenter Center for the Visual Arts in Harvard campus. Corbusier defined the ramp as the path connecting the campus, rather than access to the building entrance. Therefore, question is whether the ramp was built for the function of connecting Quincy St. and Prescott St or not. However, route connecting two streets already exists in the outer space of ground level (See the plans of 3 rd floor and the ground floors in Fig. 2,3). ${ }^{10}$
That is, the ramp has another intention in addition to function of connecting two streets physically. Corbusier described the experience of moving along the ramp of Carpenter Center for the Visual Arts as follows. "The road of access is a new road for walks or to pass through the campus. It rises gradually above the ground to reach the level of the Three-Dimensional Department and afterwards to reach the Two-Dimensional Department. From there it descends and is connected with the extant path of the campus."11 As described here, the ramp completely separates the $3 \mathrm{rd}$ floor into two spaces. Corbusier's description on the 'architectural promenade" is important. "An architecture must be walked through and traversed. ...our man has two eyes set in the front of his head, and he stands six feet above the ground and looks ahead. These biological facts are enough to damn the whole batch of plans that

\footnotetext{
${ }^{10}$ Carpenter Center is between Quincy Street and Prescott Street. The site for Carpenter Center was the empty lots which faces Fogg Art Museum and Faculty Club. The Quincy Street is the busy roads connecting to the Harvard Yard. Prescott Street is the area where school residence densely located, which means that students, faculty members and Cambridge residents frequently go through.

${ }^{11}$ Presentation by Corbusier on June 8, 1960. Sekler \& Curtis, Le Corbusier at work- the genesis of the Carpenter Center for the Visual Arts, Harvard University Press, p.95, 1978
}

have the wheel revolving around a fictitious pivot. Thus, equipped with his own two eyes and looking straight ahead, our man walks about and changes positions, applies himself to his pursuits, moving in the midst of a succession of architectural realities. He reexperiences the intense feeling that has come from that sequence of movements. This is so true that architecture can be judged dead or living by the degree to which the rule of movement has been disregarded or brilliantly exploited"12 The architectural promenade that Corbusier mentioned emphasizes human movement and sensible experience, particularly visual experience.

If we assume that ramp of Carpenter Center exists for linking the streets on each side of the site and also visual experience of observers, "What to see" and "what to be shown" become important matters with the physical movement of observers. The ramp of this building penetrates the site in diagonal direction. It means the longest path connecting two streets. The path from the peak of ramp declining to the direction of Prescott Street is the only place to see all four workshops interior space at the same time. ${ }^{13}$

\section{(4) Workshop for Arts Education}

Workshop ${ }^{14}$ consists of simple shape of two slabs, round columns and the independent skin wall. Following is the explanation of Corbusier on external wall. "The facades are either blank or provided with sun control (brise-soleil). The "fourth wall of the room" is thus achieved. These are not windows, it is a double system of sunlighting using glass planes which can be cleaned inside and out, and supplied with aérateurs assuring "cross ventilation". A third type of lighting exists: the "ondulatoires" to each side of the ramp which runs through the building."

${ }^{12}$ Le Corbusier, Talks with students from the schools of architecture, Corbusier's explanation of architectural promenade in the conversation with Beaux-Arts students during World War 2 in 1942. The Urion Press, p.p. 4445,1961

${ }^{13}$ Configuration of Carpenter Center: The underground is used as film archive, 1st floor has the footpath to the external space by pilotis, exhibition hall and lobby. 2nd and 3rd floor has workshops for arts education and is penetrated by ramp. 4th floor has the exhibition hall again, and 5th floor is used as small cafe and roof garden.

${ }^{14}$ There is a mention on the program in Oeuvre Complète 1957-65. "Program for Carpenter Center for Visual Arts is totally different. ... The unique goal of this facility is to make people feel interested and desire for the works of combining the manual artwork with spirit of present generation." There was no faculty who would decide which type of workshop would be required because Harvard University does not have visual art major. What types of workshop would be created depends on the decision of architect.

${ }^{15}$ Contents of letter of Corbusier sent from the Paris office to the Cambridge along with drawings on Feb. 28 1961.- Design of Carpenter Center for the Visual Arts was conducted with communication between local architect at Cambridge with Corbusier office in Paris. Corbusier not only explained details of work instruction, but also added his own languages that American architect could not easily understand. Sekler \& Curtis, Le Corbusier at workthe genesis of the Carpenter Center for the Visual Arts, Harvard University Press, p.165, 1978 
Table 1. Building skin components

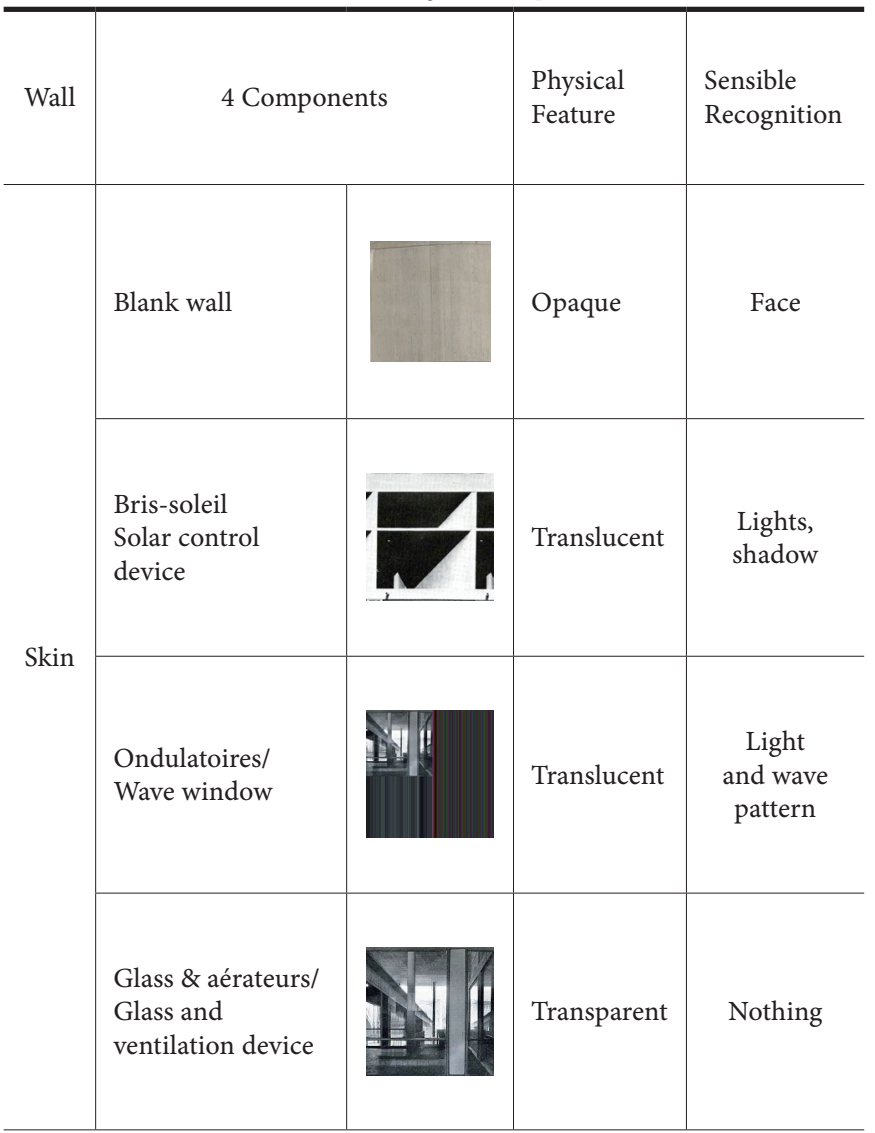

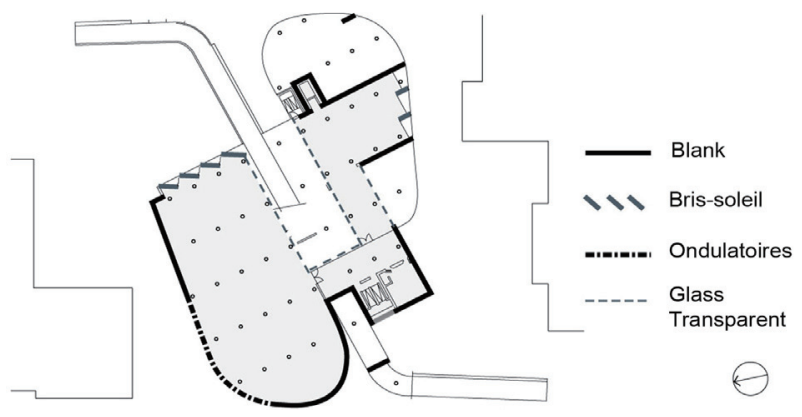

Figure 4. 2nd Floor Plan-Shows 4 types of exterior wall configuration of the workshop

Corbusier classified the formation of external wall into four kinds. That is, the first one is the wall without anything, the second is brise-soleil, the third is ondulatoires, and the fourth is the glass wall with transparent glass panel and aérateurs system. Table 1 shows summary of 4 walls forming the workshop. Fig. 4 . shows the explanation on the location where external wall with 4 elements is formed in the 2 floor plan.

Among them, the wall between facing two workshops is double structure of glass and ventilation device(aérateurs), called the 4th wall by Corbusier. He said "It is not Window." It gives us important clue that glass is the materials of wall rather than materials of window. Because the glass wall is physically transparent, nothing can be seen from the observer's visual sense. That is, the wall is removed.

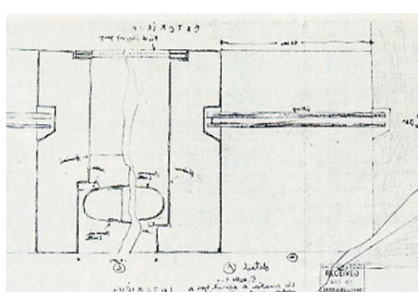

Figure 5. Joint Detail of aérateurs 1961, 7, 22.

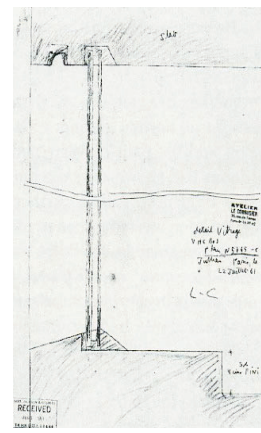

Figure 6.

Section Detail of Glass Facades -

1961, 7, 24.
Such intention also appears in construction details glass wall (See Fig. 5,6.). In order to support large size glass, vertical and horizontal metal frame were required. The horizontal frame was inserted to the ceiling and vertical mullion was replaced with ventilation device (aérateurs) so that the framework disappears between two slabs. Consequently, observers on the ramp feel as if there is nothing.

Corbusier said "The facades are either blank or provided with sun control (brise-soleil)." ${ }^{36}$ Diagonal wall of brise-soleil is aligned in parallel to the street. It provides visual obstacle between inside workshop and outside observers. As a result, vision inside the workshop was planned to open only in the glass wall between workshops where the ramp passes through. That is, the ramp becomes the only place of visually recognizing interior space

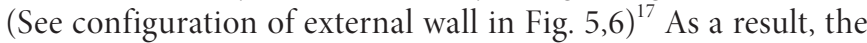
pedestrian enters the ramp with limited information about inside and sees the art works inside the workshop while going down from the peak point of the ramp passing through the building. Maximization of such visual experience was possible with complete hiding of views inside the workshop. (see Fig.7,8)

It reconfirm that the purpose of ramp is not just connecting campus also visual experience that occurs along with movement of observers. Transparent wall of workshop was the device that makes the observers recognize workshop as one space in visual sense.

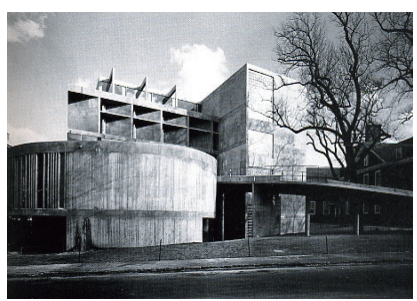

Figure 7. View from the Quincy Street

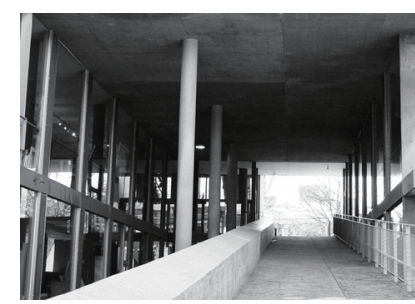

Figure 8. Ramp toward Prescott St.
${ }^{16}$ Sekler \& Curtis, Le Corbusier at work- the genesis of the Carpenter Center for the Visual Arts, Harvard University Press, p.165, 1978

${ }^{17}$ Blinding internal views also appear on the staircases and exhibition hall at the 1st floor where windows can be placed, except the workshop. First of all, the window of the staircase was finished with translucent glass block; it allows lights to penetrate inside but restricts the viewing. While the window was used for the external part of the exhibition hall on the 1st floor, pillar of ramp restricts the direct view. 


\section{(5) Structure and Mechanical System}

Technical system and finishing detail were applied for visual recognition of observers. Siegfried Giedion criticized the design of workshop space for the "hollow spaces around the workshop pilotis." ${ }^{18} \mathrm{He}$ found to be rather disappointed at the complete shape of the Carpenter Center. It is the criticism that the interior of the building does look a bit like a warehouse without spatial exciting.

In the interior space of workshop, only you can see is the column grid, the rectangular shaped and the very smoothly finished floor and ceiling. According to the initial drawing presented in 1960, structure of Carpenter Center consists of post and lintel reinforced concrete. (Fig.9,10) this is different from the final constructed version of project. In order to understand Corbusier's intension, we have to follow the design change process. In the technical note of Huson Jackson, America side engineer, "There is no indication in this sketch of any means of distributing heating or ventilation to the perimeters of the building in the slab system and no chance to bring it up from below because of the building design." ${ }^{\prime 9}$ It made Corbusier very embarrassed, because mechanical airconditioning system for workshop space requires massive volume of supply and exhaust ducts. Corbusier decided to introduce

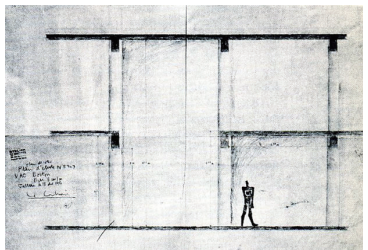

Figure 9. Section Drawing by Corbusier Office 1960, 12,19

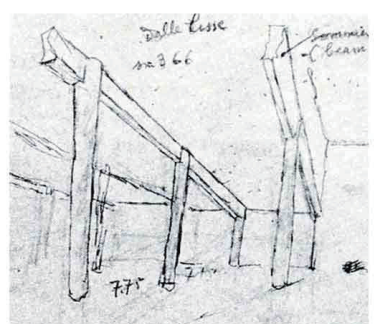

Figure 10. Sketch of Corbusier 1960, 12, 18.

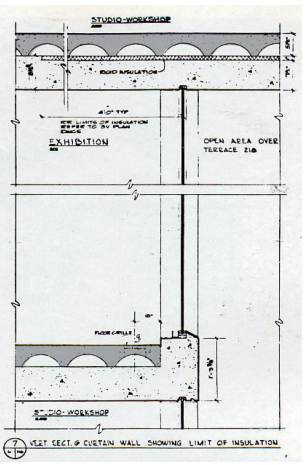

Figure 11. Section Detail Gray area is 'Airfloor'. Mar. 27, 1962 new system, called "Airfloor" that buries air supply ducts in doublelayer concrete structure, in order to satisfy the requirements of airconditioning in American building code (Fig. 11).

Because of this, the supply duct disappeared from the ceiling, but return duct still should be installed on the ceiling. Corbusier came up with idea using ventilation window (aérateurs) and persuaded to satisfy legal requirements for exhaust, and in the end removed the exhaust duct as well. ${ }^{20}$ Furthermore, he changed the structure

\footnotetext{
${ }^{18}$ Siegfried Giedion is a person who persuaded Le Corbusier to accept design of Carpenter Center for the Visual Arts by Corbusier. He started to give lectures at Carpenter Center for the Visual Arts one year before completion of Carpenter Center found to be rather disappointed at the completed shape of the center.

${ }^{19}$ Sekler \& Curtis, Le Corbusier at work- the genesis of the Carpenter Center for the Visual Arts, Harvard University Press, p.p.134-136, 1978

${ }^{20}$ See the correspondence of Corbusier sent to Sert on Nov. 6, 1961. . - In
}

system to the flat slab structure composed of columns and slabs without beam. Consequently, the ceiling and floors are viewed as one continuous slab by hiding all mechanical equipment system inside. Ramp is the place where such formal feature is most conspicuous. That is, the ceiling of the workshop on the 2nd floor and floor surface of 3rd level look like one plate suspending in the air due to transparent glass wall. (See Fig. 12)

In particular, 3rd floor slab form one continuous surface and causes confusion as if the observer over the ramp feel like being inside the workspace. Such spatial recognition is more emphasized by finishing detail
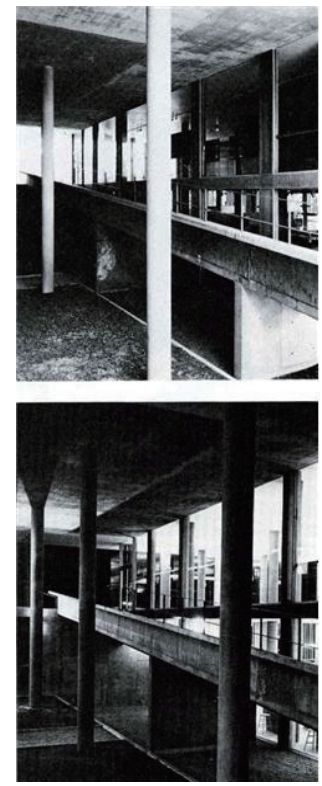

Figure 12. Workshops of $2^{\text {nd }}$ and $3^{\text {rd }}$ floor

\section{(6) Finishing of Carpenter Center for the Visual Arts}

Exterior Finish of Carpenter Center is basically the exposed concrete and used relatively various colors and finishes for interior space even if no color was used for exterior. Corbusier requested finishing of ceiling, wall and floor of the indoor space with detailed order.

First of all, Le Corbusier indicated that all pilotis were to be left unpainted, Ceilings were to be painted white, floors finished in "opus optimum" concrete or terrazzo, and walls painted in various colors. In his actual order note, "fairly smooth concrete articulated like the ramp with a variety of Modular dimensions, all in all resembling a series of ladders laid side by side with different rung widths and spacings." ${ }^{21}$ Square-shaped bottom joints are expanded to the external space and also applied to ramp, a path between Prescott St. and Quincy St. By changing the finishing with same materials of the surface from roughness to softness inside, people can recognize where they are with sense of touch. For the second floor, which was visible on the ramp, black terrazzo was used with brass joint into square diagonal arrangement so that the crossing line passes through the center of pillar. And he finished the 3rd floor with white paints over the terrazzo. ${ }^{22}$

Such detailed description on finishing was designed to use different colors and finishing for 1st, 2nd and 3rd floor so that they are recognized different space. The lobby on the first floor has the visual similarity inside and outside, but was set to feel the transition of space by different finishing on floors. For workshop shown from the ramp, surface of the 2nd floor was set to black and 3rd floor to white so that observers may feel they are the one double height space. (Fig. 12)

the letter, aérateurs' emphasized it is the device used and verified in his own project several times as well as the importance of natural ventilation. FLC J3-7 19

${ }^{21}$ Sekler \& Curtis, Le Corbusier at work- the genesis of the Carpenter Center for the Visual Arts, Harvard University Press, ,p.185, 1978

${ }^{22}$ Ibid.,p. 185 


\section{(7) Disappeared Interior Ramp}
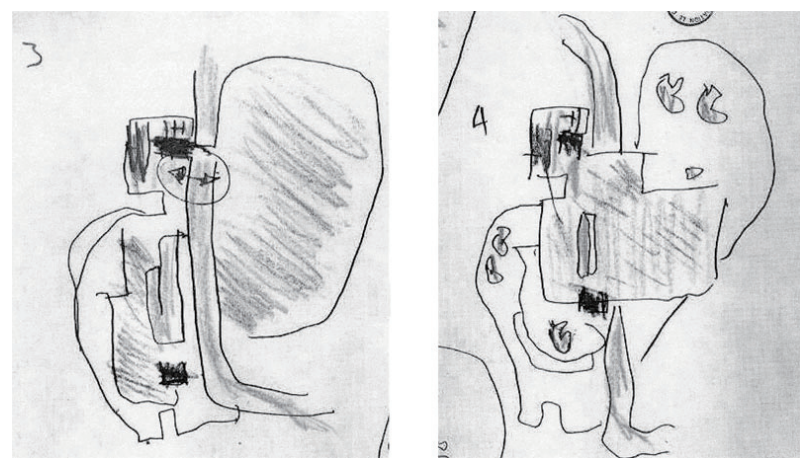

Figure 13. 3rd, 4th floor plan sketches of Corbusier (Year not known)

Corbusier Foundation (FLC \#J3-8, 91)

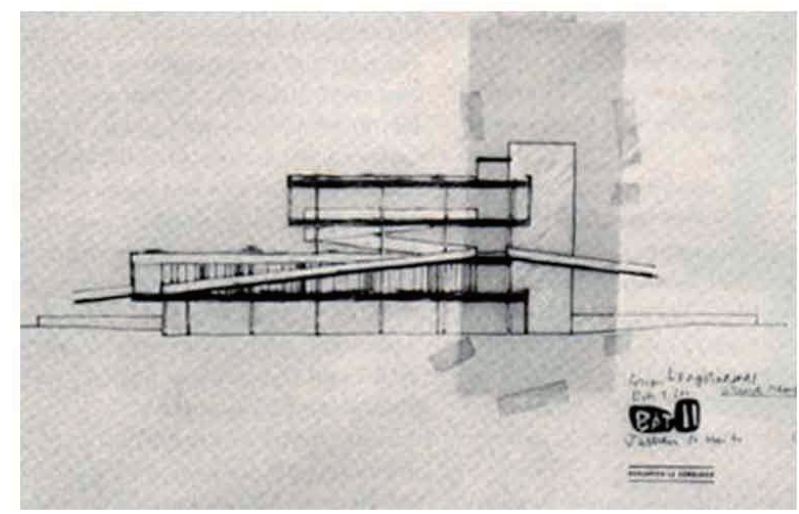

Figure 14. Section of Initial Proposal May 10, 1960, Drawn by Corbusier Office

In the initial proposal of Carpenter Center, external ramp not just penetrates building but also expands to interior space going all the way up to the 4th floor where a roof garden is and exhibition space. The Sketches (Fig 13) and the section drawing (Fig. 14) prepared by Corbusier office showed interior ramp clearly. At the first proposal, the external ramp and internal ramp were planned to have continuous circulation like in Villa Savoye. However the internal ramp was not constructed in complete building due to request of school. 'Complete Work' (Oeuvre Complète 1957-65) showed very interesting picture. In this book Le Corbusier used the plan containing internal ramp which never constructed. 'Fig. 15' shows the drawing used in 'Complete Works (Oeuvre Complète 1957-65)' and 'Fig. 16' shows the drawing of building actually constructed. In the end, Corbusier use different drawings in 'Oeuvre Complete (1957-1965)' on purpose. ${ }^{23}$

\footnotetext{
${ }^{23}$ See the 2nd illustration, Le Corbusier, Oeuvre Complète 1957-65, Birkhauser ,p.55, 2006 (1965).
}

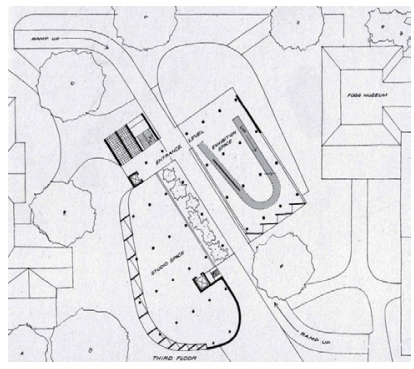

Figure 15. $3^{\text {rd }}$ floor plan shown 'Oeuvre Complète 1957-65'

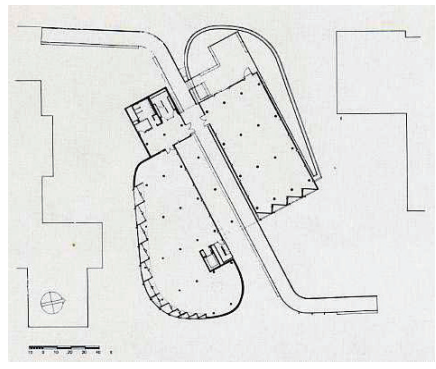

Figure 16. 3rd Floor Plan Actually Constructed

Curtis (78), p.347 Appendix
It implies that Corbusier wants continuous movement through ramp which not just penetrates building but also continues inside the workshops where arts works are located. It continued the itinerary through the internal ramp and expanded to the roof garden through exhibition space on the 4 th floor. It also confirms the fact that ramp is not a simple foot path but the active device for architectural experience.

\section{CONCLUSION}

The critique that Carpenter Center does not have interesting space inside and consists of simple warehouse type studio space and a big ramp penetrating building is caused by misinterpretation because the building has been analyzed by final shape rather than by architect's intentions within design process.

As Corbusier himself mentioned, ramp is not simple access to the building but plays a role of path for observers. He explained that it connects and expands to the campus. ${ }^{24}$ The pedestrians of ramp are not restricted to users of Carpenter Center, but include all students, other faculty members, staffs and visitors in Harvard University. That is, relation between the pedestrians and actual users of building means an encounter between the public and progressive arts. The best method to clarify the symbolic meaning of "Meeting place of young people interested in experimenting with the visual media" is to openly show the way to produce visual arts

It could be explained as the reason why he designed the ramp to penetrate the workshops through the longest itinerary. And also architect's intention to maximize sensible recognition of arts works through workshop space from the ramp.

First, external wall of carpenter center consists of one of four kinds of wall system independent from structure. 1) Opaque, 2) Light control device 3) Ondulatoires, 4) Transparency and ventilation device. Glass wall, which corresponds to transparency among them, is used between two workshop spaces facing the ramp. On the contrary the facade from two streets consists of brisesoleil, ondulatoires, and empty walls. Such configuration of external walls made the ramp as the only place to visually recognize the arts works.

Second, his intention to hide physical properties of glass wall for

24 "A new road for walks or to pass through the campus"-contents of Corbusier's presentation on June 8, 1960. Sekler \& Curtis, Le Corbusier at work- the genesis of the Carpenter Center for the Visual Arts, Harvard University Press, p.95, 1978" 
'transparency' and to make wall look like disappearing is identified at the construction detail. Hiding of glass frame emphasizes physical features of transparency. Furthermore it means that there is nothing conceptually. Transparent wall makes observers outside and artists inside to recognize sharing of one space sensibly. ${ }^{25}$

In order to satisfy demanding conditions of American building code, Corbusier collaborated with engineers and changed the structure system from the initial scheme. In the end, he insisted on forming integrated structure with mechanical equipment like ideal plate with columns and slab. This intention is most clearly found on the workshop at the 2nd and 3rd floor where the external wall is configured with glass so that plate-type slab is exposed and looks like suspending on the air. The place where it can be observed is the over the ramp descending toward Prescott St. direction.

Fourth, external wall and columns strictly were finished with single material of exposed concrete, while the interior ceiling and floors are prepared with different finishing and colors by each floor in order to experience continuous expansion at the same level. In particular, 2nd and 3rd spaces are recognized as the single twostoried space.

Like this, Carpenter Center for the Visual Arts specifies the person who would experience the building as the most people in the campus and expands the role of ramp to the architectural experience of passenger rather than accessing to the building. Furthermore, Corbusier used the drawing of un-built ramp in the last 'Compete Works (Oeuvre Complète)'. It shows his intention of connecting the exterior ramp to the interior space and expanding architectural experience all the way through from ground to the roof garden. Through the process of decision making of design elements such as, configuration of the exterior wall, choice of structure and mechanical system, window system, orders of finish material, and colors, a ramp of carpenter center could be understood in terms of extension of human experience of architectural promenade.

\section{REFERENCES}

Beatriz Colomina. (1996) Privacy and Publicity Modern Architecture as Mass Media, MIT Press.

Carlo Palazzolo(Editor). (1991) In the footsteps of Le Corbusier, Rizzoli International.

Eduard F. Sekler \& William Curtis. (1978) Le Corbusier at workthe genesis of the Carpenter Center for the Visual Arts, Harvard University Press.

Henry Russell Hitchcock. (1996) Le Corbusier and the United States, Zodiac.

Kenneth Frampton. (2001) Le Corbusier, Thames \& Hudson Inc.

Le Corbusier. (1929, 1991) Précisions. The MIT Press.

Le Corbusier. (1929, 2006) Oeuvre Complète 1910-29, Birkhauser .

Le Corbusier, (1965, 2006) Oeuvre Complète 1957-1965, Birkhauser.

Le Corbusier. (1961) Talks with students from the schools of architecture, NewYork, The Urion Press.

Stan Allen. (2000) PRACTICE architecture, technique and representation, Routledge.

William J.R. Curtis(1986) Le Corbusier Idea and Forms, Phaidon.

FLC(Le Corbusier Foundation) Archive \# VAC J3-08-91 97

FLC(Le Corbusier Foundation), Archive \# VAC J3-7 1-41, 71-80, 82-367 (Correspondences between L.C. - José Luis Sert)

(Received September 26, 2011 / Accepted June 16, 2012)

${ }^{25}$ As explained, vertical and horizontal structure supporting glass was hidden. Horizontal frame was inserted to the bottom and ceiling and ventilation window plays the act of vertical frame. In the ramp, only glass was shown 